\title{
Translator's Introduction
}

Now, when comedy hereabouts appears to be dead, or in a profound coma, it is a mistake, perhaps, to bring forth this work of mirth from another age, another language, another hemisphere. At least, the unwary reader should be put on his guard. In these pages he will find no redblooded realism, no naked women, no heavy breathing, no rapid pace, no raw meat for slavering jaws, not even any strange sexual perversions. Indeed, anything in the way of sex in this book will come under the heading, "comedy."

Published in 1904, Esaú e Jacob has the Rio de Janeiro of 1869-1894 as its setting. There are horse-drawn carriages, tipping of hats, and other manners from that faraway time and place. The fictional personages mingle in, and shadow forth, the events that led to the formation of the Republic of Brazil; the revolution itself is shown in the light of their various reactions to its various stages. One of these creatures of Assis' brain even has an audience with the historical Marshal Floriano Peixoto: it is a droll confrontation. But these comic characters and events are transformed in the light of their own greater significance, and the stronger colors of allegory, theme, and symbol fill our eyes. For, with this, his eighth and penultimate novel, Machado de Assis' narrative power reached its apex. This is the most tightly integrated of all his novels-a work that is wise, delicate, loving, gently funny, but intellectually conceived. To fathom it one must penetrate above, beneath, and deep within its story. It is not only a portrait of Brazil, it is the way of men in society in general. And the method of nar- 
ration is so subtle, so strangely modern that it still fascinates and baffles.

Yet, the guideposts are there; the important thing is not to rush past them with a careless glance. The title, for example, is a key to the book's meaning-if we interpret it in connection with the epigraph that appears on the first page of Ayres' narrative. Title and epigraph will lead us to an understanding of the first chapter, the first to the second, and so on. But, if the reader hurries past the epigraph, say, or assumes that the title Esau and Jacob refers to some Old Testament story, then he is in for endless obfuscation and bewilderment.

In his foreword, Machado de Assis informs us that the name that Ayres, the fictitious author of the novel, gave it was Last (Ultimo), and he implies that he does not understand why Ayres gave it that title. Yet, Machado de Assis himself sold the novel to $\mathrm{H}$. Garnier, his publisher, under the title Ultimo; and it is still, today, on the manuscript of the work, which is in the Brazilian Academy of Letters in Rio de Janeiro. Indeed, Machado de Assis did not change the title to Esaú e Jacob until after galley proofs.

It would seem that Machado de Assis decided Esau and $J a c o b$ was a better title. Why? Did the first title bear any relation to the final one? Was the title Last really given to the narrative by the fictitious Ayres?

Let us consider the final title, Esau and Jacob in the light of the epigraph. The epigraph is a line of Dante. And Dante, in his Paradiso, used Esau and Jacob, and in particular Esau's red hair, to symbolize God's practice of conferring diverse natures on men, even on sons of the same father and mother-twins-so that not only do brothers not necessarily resemble each other, children often do not resemble their parents. But the epigraph is a line from the Inferno (Canto V, line 7), though it too has ref- 
erence to predestination - to souls predestined not to fulfill their destiny.

In Chapter XII, this line from the Inferno is applied to guests at the home of the banker Santos for being "insipid" bores. Chapter XIII, however, seems to indicate that it refers to a whole society. This is borne out by another quotation. In Chapter XXXII, which narrates the old diplomat's retirement to his native land, we are told that he withdrew from the society of men, taking as his device, "I fled afar off, and dwelt in solitude." The quotation is from the Vulgate, Ps. 54:8. The rest of the psalm relates how the singer came back and found Philistines in the city, and "saw the city all full of wickedness," and in the marketplace "nothing but usury and fraud." The psalm and the quotation from the Inferno seem to refer to the same persons. There is the further detail that the line from the Inferno is from the passage where Minos is consigning sinners to the various circles of $\mathrm{Hell}$ by the proper number of turns he gives his tail. In allusion to this, the banker Santos' tongue (Chapter LXXXIV) "made seven turns in his mouth"-which would land him in the seventh circle with the usurers, where he properly belonged.

When the character Ayres used the line of Dante, he was referring to a segment of the society he found in Rio de Janeiro in the 1870's; Ayres, the narrator, applied the verse to the whole narrative and everyone in it. He would perhaps have excluded all the women, because he liked the ladies, and in particular Santos' wife, Natividade, with whom he was in love. Machado de Assis, however, might well have intended to include everyone among these souls. But, when he turned over the narration of this novel to the ex-diplomat Ayres, he let him have his way. Although the narrative is in the third person, Ayres (like Julius Caesar) introduced himself as one of the actors. As narrator, Ayres remains rigidly in character: he is always the 
old diplomat; he is never Machado de Assis. As actor, he bears out the character of the narrator. And, in a sense, the story is his. True, his characters are free agents and autonomous: he only records their acts, words, and thoughts; he even defers to the reader in matters of interpretation; but, with each succeeding chapter, the character of Ayres grows clearer, takes on added life and meaning.

In Chapter XIII, Ayres partially explains his literary method. In alluding to the line of Dante that the actor Ayres wrote in his notebook, he says:

Well, there is the epigraph of the book, if I should wish to give it one, and no other occurred to me. It is not only a way of rounding out the characters and their ideas, but it is also a pair of spectacles with which the reader may penetrate whatever seems not quite clear or wholly obscure.

Furthermore, there is an advantage in having the characters of my story collaborate in it, aiding the author in accordance with a law of solidarity, a kind of exchange of services between the chess-player and his men.

If you accept the comparison, you will recognize the king and the queen, the bishop and the knight, and that the knight cannot become a castle, nor the castle a pawn. There is of course the difference of color, white and black, but this does not affect the power of each piece to move, and finally one side or the other wins the game, and so goes the world. Perhaps it would have been a good idea to insert, from time to time (as in chess books), the favorable positions or the difficult ones. With no chessboard, that procedure is a great aid for following the moves, but then it may be that you have enough vision to reproduce the various situations from memory. Yes, I think so. Away with diagrams! Everything will go along as if you were actually witnessing a game between two players or, to be more precise, between God and the devil.

That is, the good and the evil in their natures make the action; the characters write the story. At the same time, the collaboration between the two Ayreses is neat and 
effective. The banker Santos, for example, did not stand high in Ayres' opinion-I am speaking of the narrator: there are insinuations from the start, and Santos is permitted, again and again, to display his more unlovely and asinine traits, but it is Ayres the actor who is assigned the job of giving Santos the coup de grace. (After all, he was in love with Santos' wife.)

"Your cigars are superb." [Ayres says to Santos.]

"These are new ones. You like them?"

"Superb."

Santos rejoiced in this praise: he considered it a judgment aimed straight at his person, his merits, his name, the position he held in society, his house, his estate, his Bank, his waistcoats. That is perhaps too much: it will serve as an emphatic way of explaining the strength of the bond between him and his cigars. ... .

These were the suspicions that roamed about through Ayres' brain, as he gazed mildly at his host. Ayres could not close his eyes to the aversion this man inspired in him. Not that he wished him any harm exactly. He might even have wished him well, if there had been a wall between them. It was his person, his feelings, his remarks, his gestures, his laugh, the whole soul of the fellow that offended him.

As already mentioned, narrator Ayres presses historic personages into his service, and, worst of all, he puts the reader to work. He leaves blank spaces in his narrative for the reader to fill in. "The attentive, truly ruminative reader," he tells us in Chapter LV, "has four stomachs in his brain, and through these he passes and repasses the actions and events, until he deduces the truth which was, or seemed to be, hidden."

From the title Esau and Jacob, the epigraph, and Ayres' psalm, we may fairly surmise that this society which forms the subject matter of the novel is not the child of the previous generation, and that it is predestined by its nature not to fulfill its destiny. 
What was its destiny? Speaking historically, one answer would be "to found the Republic."

Armed with our spectacles and four stomachs, let us now look at Chapter I: its title seems propitious, "Things fated to be."

A society woman, Natividade, accompanied by her sister, climbs the steep, rocky hill, Morro do Castello, to consult a fortuneteller about her twin baby sons. The seeress predicts that a great destiny is in store for them: they will be great! In what way? asks the mother. That, says the fortuneteller, rests with the future. And she adds the, apparently, gratuitous information that the twins fought in the womb and will continue to do so in the world.

Who are these babies, who is this mother? The hill mentioned in the initial sentence is a clue to their identity. The Morro do Castello is here a monument of Brazil's past, a symbol of the history of Brazil's capital. As Gastão Cruls writes in his Aparência do Rio de Janeiro, there was no real city until the first Portuguese settlement removed to this rock. It was from there that the Portuguese drove the French from the bay in 158r. It was on this hill that Father Manuel da Nobrega founded the great Jesuit college in the sixteenth century. Anchieta taught there, and preached in the Jesuit church that bore the date 1567 on its lintel. It is clear that this lady, Natividade, has an intimate relation to the Morro, to the old Brazil, if she is not Brazil herself.

In 1871, when Natividade went there, all this early civilization was long since gone, church and college had been abandoned by the Jesuits. A fortuneteller reigned there in 1871, Ayres tells us. The situation is summed up by the "penance" of the ladies' feet and by the title of Chapter II-playful allusions to Dante's Mt. Purgatory (which was also located in the Southern Hemisphere). 
With Dante's mountain of repentance, the ascent became easier the higher one went; with the Rio hill it was "better coming down than going up." This was a society that consulted fortunetellers, though the more sophisticated, like the eminent banker Santos, might go in for spiritualism. The Church and its culture had become a shabby thing, good enough for poor people and the dead, a cheap charity for the wealthy, who also used its crucifixes as personal lucky charms. The "Nobrega" of Ayres' tale is a begging lay-brother who steals from the collection bowl. This is an irresponsible, superficial society-in passions, morals, mentality, and religion, a society slightly contemptuous of things Brazilian, whether it be language, thought, art, manufactures.

The fortuneteller from the wilds, the cabocla-what is she? She probably represents the three racial strains of Brazil's substructure. In her are combined gentleness, innocent beauty, rhythmic grace, and the mystic ignorance of Indian, Negro, and Portuguese folklore and superstition. But she is the voice of destiny: "destiny" to Machado de Assis was synonymous with "nature." One feels she is something more basic than Rio's society at the end of the century. There seems to be an affinity between her and this mother. Natividade, we learn later, did not resemble her father; she was not the daughter of the Second Empire. She had a sky-blue soul like her grandfather's: she believed she was beloved of fortune. Although she consulted a fortuneteller about her babies' future, she had never once doubted that her sons were destined to have a great future. Brazil, land of the future! When did one last see that phrase? No longer ago than this morning's paper.

This lady is Brazil. She is married to a banker; she is faithful to her banker; she cannot be seduced by an intellectual, even though he is a man of good sense, and the 
banker is not. These babies are her sons, identical twins born in the year of the Republican Manifesto. They have a great destiny before them-a destiny they are, paradoxically, destined never to attain completely, because they are also destined never to agree, never to actually disagree. Their quarreling has no grand significance as in Genesis, where two nations struggled in Rebekah's womb. There is no Biblical Jacob in this story. The fighting of the twins, Paulo, the liberal, and Pedro, the conservative, has no political significance. Politics is only an excuse that serves a basic need. They are identical twins; Natividade recognized them as "two pieces of herself." Where the wish of their mother was concerned, they were like a man talking to himself. They represent the mutual attraction and repulsion that exists between individual human beings.

Now, we can see why Machado de Assis changed the title to fit the greater meaning. Last would refer specifically to the age, perhaps echoing a verse from Matthew, a gospel that Ayres quotes more than once: "And the last state of that man is worse than the first. Even so shall it be also unto this wicked generation." In other words, Last would restrict the author to a time, a place, and a subject - Rio society in the last quarter of the nineteenth century. The title Esau and Jacob embraces the whole destiny of a people. By carrying forward the message of the epigraph, it explains how the Republic was born of this society to which it bore no resemblance-just as the youthful heroine, Flora, did not resemble her parents. As Ayres remarked of her with allusion to Dante, "Children do not always reproduce their parents." Flora was the opposite of hers. They were working politicians of the old school, identical except in will power. Her father was a party man, conservative, weak-willed, not conspicuously honest or dishonest--just so-so. Her mother had tremendous drive and ambition. Like Lady Macbeth, she counseled her hus- 
band, in effect, "Look like the time . . . but be the serpent under it." She was not inciting to murder, however; she was merely trying to get him to change his party.

There was nothing of practical politics about Flora. There was nothing practical about her. She was given to dreams and visions. She herself was "Orpheus the sweet singer," a will-o'-the-wisp, a "fragile vase," "flower of a single morning," fit subject "for a tender elegy." There were many suitors for her hand-among them a capitalist, a bureaucrat, and young men from the provinces. But she would have none of them. She had eyes only for Natividade's sons, Pedro and Paulo, the one a conservative, the other a liberal, identical twins. And she was not content to choose one: she wanted them both. To her they were not two, but one.

Flora did not share her parents' dismay over the fall of the Monarchy. To get away from their pain, she took refuge with her piano. "For her, music had the advantage of not being present, past, or future: it was a thing outside time and space, pure idea." But, in her sonata there was "a kind of harmony with the present hour." Flora was the present, as the twins were the past and the future. She saw no difference between this past and future; they both wanted to possess this present. Love, in Machado de Assis' vocabulary, is the present, the moment; lasting love is a series of presents, of moments, and this is what life is. Early in the story, the personage, Ayres, tried to escape the present when he took as his device the verse of the psalm, "I fled afar off and dwelt in solitude." He fled into the past: into the streets of his boyhood, into old letters and memories. Like the two men who dyed their beards, he too tried to hold Time captive; but "God granted Time a writ of habeas corpus." Ayres changed his device, fled back to the present, to love: a true Dantean, he prolonged himself by living in society. 
There is a general concern, among the personages of this novel, with holding Time captive. Some try to accomplish it by making themselves new, others by clinging to the old. And many symbols multiply the images of the various aspects of Brazil, its monarchy, and its republic, for these are in, and of, time: Custodio's signboard with the legend, "The Imperial Pastry Shop," and its new paint, Perpetua's inkwell, the letter from the Marquês de Pombal to the Dutch minister, the five stars of the Southern Cross, the caboclo's song, the portraits of Robespierre and Louis XVI which were replaced by the portraits of the banker and his wife, the cushions and ribbons in the twins' bedroom, the unfinished house, the wall and the rose, Petropolis, Santos' cigars, the toilet water on Nobrega's face, and so on.

Wisdom, Machado de Assis used to say, came out of a well. The old Ayres, whose favorite authors were Homer, Dante, Horace, Erasmus, Father Bernardes, and other European classics, actually rejuvenated himself by returning to certain mineral springs in Europe. (He distrusted Brazilian spring water.) And the flower in his buttonhole is redolent of youth, innocence, young love, life. For, this old intellectual is also one of Brazil's souls. Soul, alma, is the keyword of this novel. The psyches of the various personages are all plumbed, as individuals, and as parts of a greater soul-the soul of Brazil.

For all the abstract terms in which the novel is couched, for all its deeper meaning, it is none the less a true and vivid account of a certain period of Brazilian history. Integrated into this work of symbolic fiction, we find not only the reactions of typical Brazilians from various walks of life to the historical events, but, also, in brief flashes of poetic description, such actualities as the imperial government's ball for the Chilean officers, the soldiers' march down the Rua do Ouvidor, the first ball of the Republic, 
the wild financial prosperity and speculation. Even Marshal Floriano Peixoto, in characteristic attitude, is made to add to the drollery of this book. For, Machado de Assis lived through these events: as a bureaucrat, he saw them at close hand; as a journalist, he commented on them in the press.

And this novel is no less true because Machado de Assis chose to make it a comedy, a story "without tears," chose to weave into it threads that tie in knots such various and sundry aspects of civilization as politics, religion, diplomacy, young love, old wisdom, and-perhaps most nicely of all-the naturalistic school of writing. As Ayres' "beloved Horace" put it, ridentem dicere verum / quid vetat? Like the other four of Assis' last five novels, this one satirizes the Brazilian scene and the world, Brazilian society and human nature-through characters that have a permanent life of their own. And it stands securely, a unique work of art among Machado de Assis' creations and among other works of universal genius. 
